\title{
Rancang Bangun Media Pembelajaran Alat Musik Hadroh Berbasis Android
}

\author{
Rena Roy Zulkarnaen ${ }^{1}$, Moch Nur Qomaruddin ${ }^{2}$, Sulistiyanto ${ }^{3}$ \\ ${ }^{1,2,3)}$ Prodi Teknik Elektro, Universitas Nurul Jadid \\ 1) renaroy8102@gmail.com, ${ }^{2)}$ nqomar2018@gmail.com, ${ }^{3)}$ sulistiyanto@ymail.com
}

(Naskah masuk: 12 Juli 2019, diterima untuk diterbitkan: 26 Juli 2019)

\begin{abstract}
ABSTRAK
Salah satu musik trasional negara Indonesia adalah alat musik hadroh yang biasanya digunakan ketika ada acara agama Islam. Masyarakat di Indonesia, mereka yang tertarik mempelajari instrumen musik hadroh sudah mulai terkikis oleh perkembangan zaman dan orang-orang cenderung lebih menyukai instrumen modern. Untuk menarik minat penggemar, diperlukan metode pengembangan alat musik hadroh yang mudah diterima oleh masyarakat. Membuat aplikasi alat media pembelajaran dan musik yang bisa dijalankan di handphone Android adalah merupakan bagian dari upaya peningkatkan daya tarik penggemar dan membuatnya lebih mudah untuk belajar cara bermain dan informasi tentang alat musik hadroh. Aplikasi ini dibangun menggunakan metode pengembangan MDLC yang memiliki dengan tahapan seperti berikut, konsep, desain, pengumpulan bahan, perakitan, pengujian dan distribusi, aplikasi ini dapat dijalankan pada ponsel android dan bertujuan agar mudah dibawa kemana-mana. Aplikasi media pembelajaran untuk musij hadroh secara fungsional menghasilkan sesuai dengan kebutuhan yang diharapkan oleh pengguna. Dan memungkinkan pengguna bisa berinteraksi langsung dalam proses bermain hadroh sesuai dengan mekanisme alat musik yang sebenarnya. Hasil survei diperlihatkan untuk beberapa orang, tingkat puasan yang diperoleh sekitar $80,0 \%$ yang berarti dapat dikatakan memuaskan.
\end{abstract}

Kata Kunci : Media, pembelajaran, alat musik, hadroh

\begin{abstract}
One of Indonesia's national music is the hadroh music instrument which is usually used when there are Islamic religious events. People in Indonesia, those who are interested in learning hadroh musical instruments have begun to erode by the times and people tend to prefer modern instruments. To attract fans, a method for developing hadroh musical instruments is easily accepted by the public. Making learning media and music application tools that can be run on Android mobile phones is part of an effort to increase the appeal of fans and make it easier to learn how to play and information about hadroh musical instruments. This application was built using the MDLC development method which has the following stages, concepts, design, material collection, assembly, testing and distribution, this application can be run on an android phone and aims to be easily carried everywhere. Learning media applications for musij hadroh functionally produce according to the needs expected by the user. And allows users to interact directly in the process of playing hadroh in accordance with the actual musical instrument mechanism. The survey results were shown for some people, the level of satisfaction obtained was around $80.0 \%$ which means it can be said to be satisfactory.
\end{abstract}

Keywords: media, learning, musical instruments, hadroh

\section{PENDAHULUAN}

Beraneka ragam budaya yang ada di Negara Indonesia termasuk, agama, seni dan tradisi. Ada beberapa orang yang memahami serta menyukai kebudayaan yang dimiliki oleh masing-masing Negara, yang lainnya mereka lebih memperhatikan budaya modern dibandingkan dengan tradisi budayanya sendiri.

Karena itu maka diperlukannya sebuah metode pembelajaran dengan cara modern juga, ini tidak lain adalah 
supaya kebudayaan tradisional tetap lestari dan bisa dengan sebentar dalam membelajarinya dan tidak terlalu sulit diterima oleh masyarakat modern atau generasi milenial, yang sekarang ini trend di bilang begitu. Untuk mewujutkannya diperlukan beberapa materi media pembelajaran yang akan disampaikan kepada penggunan aplikasi nanti atau yang di sebut user, dimana media pembelajaran itu harus bisa sajikan secara modern supaya kebudayaan tradisional di indonesia tidak terlupakan. Alat-alat musik tradisional di negara Indonesia ada beberapa macam, ada yang asli dibuat dari daerah setempat dan ada juga yang dari daerah luar, yang merupakan bawaan dari para leluhur salah satunya seperti alat musik tradisional rebana. Rebana bukanlah alat musik tradisional yang lahir di Indonesia, namun alat musik rebana telah menjadi suatu tradisi bagi kalangan muslim di Indonesia, sehingga alat musik rebana termasuk dalam alat musik tradisional yang dimiliki oleh Indonesia. Alat musik rebana pertama kali di kenalkan oleh bapak Toip dan bapak Madali sekitar tahun 1940-an. Karena masih kurangnya generasi minenial mengenal alat musik rebana maka diperlukanlah media pembelajaran pengenalan alat music rebana yang bisa di jalankan di handphone android, selain ada foto alat music, juga bisa di mainkan dengan menabuh gambar atau foto alat music tersebut di layar handphone. Alat musik hadroh ini biasanya untuk anakanak yang berada di Pondok Pesantren atau dalam hal ini para santri, maka penelitian ini adalah membuat "Rancang bangun media pembelajaran alat musik hadroh berbasis android" dari penelitian ini di harapkan dapat memudahkan, mempercepat pemahaman, ketika mempelajari cara-cara memainkan alatalat musik hadroh.

\section{Tinjauan Pustaka}

Pada tahun 2017, Jeni Nadik melakukan Penelitian, berjudul, "Aplikasi Rebana Digital Android:, dimana tujuan penelitiannya adalah Membangun Aplikasi Rebana Digital dengan menggunakan alat musik berbasis sistem operasi android. Pada program aplikasi yang dibuat dapat memberikan informasi tentang musik Hadroh atau Rebana yang dapat mengeluarkan nada dari masingmasing alat musik. Di program itu juga berisi teks gambar dan suara tentang informasi rebana. Sehingga dapat mempermudah orang yang menggunakan program media pembelajaran ini. dalam memainkan musik rebana dan bisa memahami tentang alat musik rebana secara mobile. Sedangakan saudara Arief Multi Hidayat.pada tahun 2018, yang judul penelitianya, Aplikasi Pengenalan Alat Musik Tradisional Indonesia Berbasis Android. Tujuan Penelitiannya adalah membuat alat bantu untuk pengguna dalam mempelajari dan mengetahui alatalat musik tradisional dangan menggunakan sebuah produk perangkat lunak seperti alat musik atau aplikasi lainnya, sehingga kekayaan Indonesia akan terus terjaga dengan bertambahnya penduduk Indonesia. Media pembelajaran berbasis multimedia dapat menjadi sebuah solusi dan membantu pengguna untuk mengenalkan beragam kesenian pada murid di Sekolah Dasar Negeri 1 Tamansari Sumber Malang. Sedangakan tahun 2016 ada penelitian yang dilakukan oleh Roemaldo, S., dengan judul Game Pembelajaran Alat Musik Tradisional Rebana Berbasis android. Adapun tujuan dari sistem ini adalah Membangun Aplikasi Game berupa media pembelajaran alat musik tradisional 
rebana yang bisa dimainkan di handphone android. Dengan adanya program aplikasi media pembelajaran berupa game ini dapat memperkenalkan dan memberi pengetahuan tentang alat musik tradisioanal rebana kepada semua masyarakat yang menggunakan aplikasi ini. Isi program aplikasi media pembelajarannya cukup lengkap dan dapat memberikan pengetahuan lebih untuk semakin tahu tentang musik rebana ini. Selain itu, dikarenakan adanya aplikasi mobile berbasis android yang memudahkan seluruh pengguna alat musik untuk mempelajarinya tanpa batasan waktu.

Berdasarkan 3 judul peneliitianpenelitian di atas, persamaan penelitian ini dengan hasil-hasil penelitian sebelumnya adalah sebuah sistem informasi pembelajaran dan simulasi alat musik tradisional yang dapat dijalankan di handphone android. Sedangkan perbedaan penelitian ini dengan hasil-hasil penelitian sebelumnya adalah membuat software aplikasi media pembelajaran alatalat musik hadroh untuk pemula, yang dilengkapi dengan tutorial berupatext dan video. Tutorial yang ada tentang cara memainkan alat musik hadroh beserta gambar pada posisi tangan yang benar untuk memainkan alat-alat musik tersebut, dalam aplikasi ini pengguna atau user tidak hanya dapat memaikan alat musik hadroh langsung di handphone yang mengelurkan suara ketika di klick bagian alat music tersebut, tetapi bisa juga belajar dengan membaca tutorial yang benar sehingga dapat mempercepat mengetahui dan memahami tentang alat musik hadroh atau rebana.

\section{A. Media Pembelajaran}

Media pembelajaran multimedia yang bisa dijalankan di handphone android, bisa dianggap sebagai bentuk media pembelajaran yang dilengkapi media jenis audio, text, video dan visual atau gambar, yang diketahui dapat memberi pengaruh sangat besar kepada pengguna di antara jenis media lainnya. Pembelajaran merupakan suatu sistem lingkungan belajar yang terdiri dari komponenkomponen berikut. tujuan pembelajaran, materi pelajaran, kegiatan belajar mengajar, metode, sumber belajar, evaluasi, dan media belajar. Media pembelajaran merupakan salah satu unsur yang harus tersedia dalam proses belajar. Dibandingkan dengan aplikasi komputer, menggunakan media smartphone akan lebih praktis karena memiliki bentuk dan ukuran yang kecil serta mudah dibawa akan memberikan kemudahan bagi pengguna untuk mencari suatu informasi yang di inginkan dengan cepat dan mudah.(sulistiyanto, 2018). Disambing itu bisa juga dimanfaatkan media belajar yang sesuai, maka diharapkan proses belajar dapat berlangsung dengan efektif dan menyenangkan.

\section{B. Corel VideoStudio X8}

Untuk mendesain layout atau latar belakang dan bentuk tombol pada aplikasi media pembelajaran hadroh ini menggunakan software Corel Video Studio X8. Dimana software ini dapat memberikan beberapa pilihan tools yang bagus dan pilihan untuk bisa melepaskan kreativitas user dalam membuat video yang luar biasa. Corel Video Studio X8 merupakan Software edit video yang dapat menyatukan beberapa tools baru, fitur cerdas dan peningkatan kinerja termasuk Freeze Frame dan Video Masking yaitu tools yang dapat menyajikan secara multi layer, juga adanya Audio Ducking untuk suara pro-berkualitas, dan akselerasi perangkat keras $4 \mathrm{~K}$ yang lebih 
dari 4 kali lebih cepat pada prosesor Intel Core generasi ke-5. (Corel. 2015)

\section{Audacity}

Untuk editor suara dalam pembuatan media pembelajaran ini menggunakan software Audacity, yang merupakan salah satu jenis software yang dikembangkan oleh relawan yang ingin menghadirkan audio editor terbaik yang bisa berjalan pada bergai sistem operasi atau dalam hal ini software yang multi platform audacity di distribusikan oleh GNU Genera Public Licensel (GPL). (Tim Airputih, 2010)

Beberapa fasilitas yang di miliki pada

Sofware Audacity misalnya adalah

a. Menambahkan bermacam efek suara

b. Merekam suara secara langsung lewat audactity.

c. Convert format suara.

d. Merekam suara dari komputer.

e. Memotong dan mencopy suara.

\section{Mobile Computing}

Merupakan alat komunikasi jaman sekarang yang dapat melakukan komunikasi dengan jaringan nirkabel bisa disebut dengan mobile computing. Alat ini adalah sebuah paradigma yang belum lama ini sebagai hasil dari kemajuan teknologi yang dapat melakukan komunikasi dengan jaringan nirkabel sehingga pengguna aplikasi bisa dan mampu melakukan perpindahan. Sekumpulan hardware, software, dan data. Software yang mampu atau bisa di gunakan berpindah tempat, tidak menetap dan dalam sistem terdistribusi dimana beberapa node dapat bergerak bebas dan melakukan koneksi pada jaraingan yang berbeda.

Kelebihan menggunakan alat ini adalah :

a. Bisa bebas berpindah jaringan.

b. Memiliki aplikasi yang banyak dan luas

c. Bergerak/berpidah lokasi secara bebas.

Dengan menggunakan Mobile Computing, pengguna aplikasi dapat melakukan pekerjaan dimanapun berada, serta dapat melakukan aktifitas business dengan konsep Mobile Computing sebagai berikut :

a. HP/Migrasi (Mobile/Migrasi)

b. Privasi (Privacy)

c. Keamanan (Security)

d. Otentikasi (Authentication)

\section{METODE}

Rancangan penelitian merupakan pokok-pokok perencanaan dari seluruh kegiatan penelitian yang tertuang dalam satu kesatuan naskah, pada tahap ini akan dijelaskan proses-proses dalam penelitian, metode yang digunakan dan siapa saja yang terkait dalam penelitian. Pada teknik pengembangan sistem yang digunakan pada penelitian ini adalah teknik pengembangan model Multimedia Development Life Cycle (MDLC). Model pengembangan Multimedia Development Life Cycle digunakan karena bersifat sistematis dan tahapan-tahapannya terancang dengan baik. Model pengembangan $M D L C$ ini memiliki 6 tahap yaitu, concept, design, material collecting, assembly, testing, distribution. (Luther, 1994). Adapun diagram alur dari model pengembangan MDLC dapat dilihat seperti pada Gambar 1.

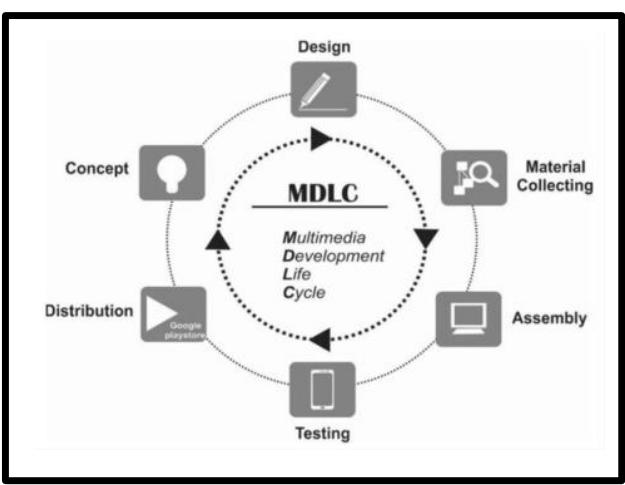


Gambar 1. Model MDLC

\section{A. Konsep}

Tahap consept (konsep) pada MDLC merupakan tahapan untuk menentukan tujuan dan siapa pengguna program (identifikasi program). Tujuannya tidak lain adalah supaya pengguna akhir program berpengaruh pada nuansa multimedia sebagai pencerminan dari identifikasi organisasi yang mengiginkan informasi sampai pada pengguna akhir. Karakteristik user/pengguna didalamnya termasuk kemampuan user/pengguna juga perlu di pertimbangkan karena dapat memengaruhi pembuatan desain. Selain itu tahap ini juga akan menentukan jenis aplikasi. Adapun aplikasi yang akan peneliti buat adalah Aplikasi "Belajar Hadroh" Sebagai acuan pembuatan aplikasi pada tahap berikutnya maka perlu disusun suatu skenario agar aplikasi yang dibuat sesuai dengan apa yang diharapkan. Skenario dari aplikasi "Belajar Hadroh" ini yaitu sebagai berikut:

- Aplikasi "Belajar Hadroh" terdiri dari tujuh halaman, yaitu halaman pembukaan, halaman menu utama, halaman Orkesta, halaman belajar memukul hadroh $(\mathrm{BMH})$, halaman materi memukul hadroh, halaman vidio memukul hadroh, halaman info, dan halaman keluar.

- Pada halaman menu utama pengguna dapat memilih menu yang diinginkan seperti Orkestra, Belajar memukul hadroh $(\mathrm{BMH})$, info dan keluar.

- Halaman orkestra adalah dimana pengguna dapat memilih salah satu alat musik hadroh untuk bermain dengan user lain secara bersamaan menggunakan smartphone yang berbeda. Dan setiap user hanya bisa memilih salah satu alat musik hadroh yang terdapat pada menu tersebut.

- Pada halaman BMH terdapat dua pilihan yaitu Materi, Video. Jika memilih materi maka akan ke menu pilihan materi alat musik hadroh jika memilih video maka akan ke menu pilihan video alat musik hadroh.

- Pada halaman info pengguna dapat mengetahui identitas peneiti.

- Pada halaman keluar terdapat dua pilihan yaitu "YA" atau "TIDAK" jika pengguna memilih TIDAK maka pengguna akan kembali ke menu awal jika memilih YA maka akan keluar dari aplikasi tersebut.

\section{B. Perancangan (Design)}

Design dalam system MDLC merupakan tahapan dalam pembuatan spesifikasi mengenai gaya, arsitektur program, tampilan dan kebutuhan material/bahan untuk program. Spesifikasi di buat sangat rinci sehingga pada tahapan berikutnya. Yaitu material collecting dan assembly. Pada tahap ini biasanya menggunakan flowchart.

\section{Material Collecting (Pengumpulan Bahan)}

Material Collecting dalam MDLC merupakan tahap pengumpulan bahan atau data sesuai dengan kebutuhan yang dikerjakan untuk membuat aplikasi media pembelajaran alat-alat musik hadroh. Adapun Bahan-bahan tersebut, antara lain gambar, audio, video dan lain sebagainya. Pengumpulan bahan yang digunakan diperoleh melalui observasi dan wawancara dari ketua Jamiatul hadrah Pondok Darul Lughah Wal Karomah, Pesantren Nurur Rahmah, dan Ponpes Nurul Jadid. 


\section{Pembuatan (Assembly)}

Pada tahapan ini pembuatan atau assembly dalam MDLC adalah tahapan pembuatan semua obyek dimana pada tahapan ini biasanya menggunakan sotfware dan perangkat keras.

\section{E. Pengujian (Testing)}

Tahap pengujian atau testing dalam MDLC merupakan pengujian yang akan dilakukan kemudian setelah menyelesaikan tahapan pembuatan (assembly) dengan menjalankan aplikasi/ program dan melihatnya apakah ada kesalahan atau tidak. Pada tahap testing ini, pengujian dilakukan dengan dua cara yaitu pengujian secara internal yang menggunakan metode black box yang akan diuji oleh pembuat dan beberapa orang yang dianggap berkompeten dalam bidang tersebut, serta pengujian dilakukan secara eksternal bukan internal dengan melakukan uji coba kepada user yaitu semua pemain hadrah Pondok Pesantren sehingga didapatkan apa kekurangan serta dimana kelemahan yang muncul dari aplikasi yang dibuat oleh ini. Jika masih masalah yang belum sesuai maka akan dilakukan perbaikanperbaikan.

\section{F. Distribution (Distribusi)}

Dari hasil pembuatan software atau aplikasi ini di kemudian hari bisa di distribusikan melalui Google Play Store. Mengapa Google Play Store yang dipilih ? karena lebih mudah pendistribusiannya pada perangkat seluler dan sangat mendukung sistem operasi Android. Selain itu pengguna juga dapat dengan mudah men-download-nya.

\section{PEMBAHASAN}

Dari pengumpulan data pada kegiatan penelitian ini kemudian di proses untuk pembuatan aplikasi media pembelajaran berbasis android. karena data tersebut akan membantu proses penelitian yang akan diteliti. Pada teknik pengumpulan data harus cermat dan benar. Proses pengumpulan data yang telah dilakukan dengan melakukan observasi, studi literatur dan berikutnya adalah wawancara. Adapun hasil dari pengumpulan data sebagai berikut :

Berdasarkan hasil observasi yang di lakukan pada tempat penelitian yang memiliki kelompok anggota hadroh di probolinggo, diperoleh kesimpulan bahwa proses kegiatan belajar mengajar hadroh yang diterapkan saat ini masih kekurangan alat musik hadroh dan kurangnya waktu untuk belajar memainkan alat musik hadroh.

\section{A. Flow Chart Menu Alat Musik}

Pada Gambar 2 berikut ini adalah algoritma dari menu alat musik

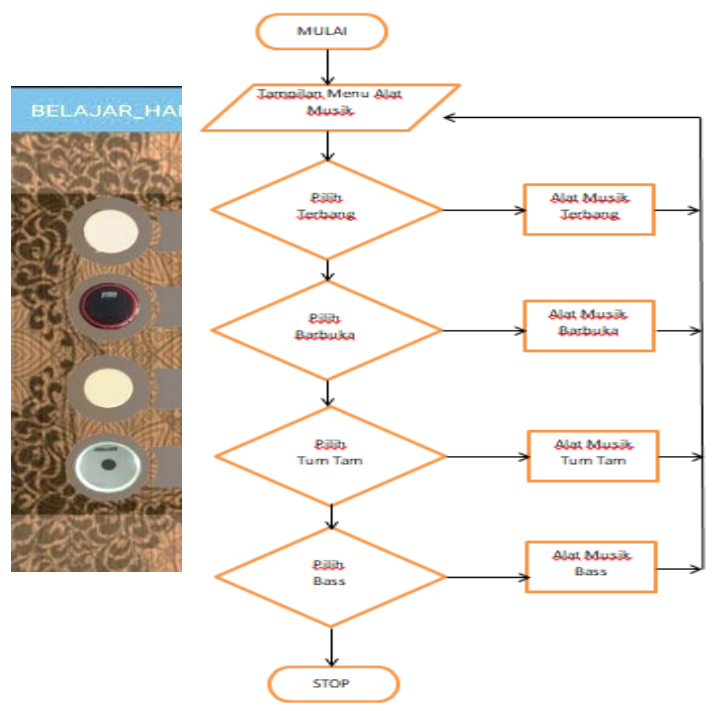

Gambar 2. Flowchat Menu alat musik

\section{B. Tampilan Menu Alat-alat music hadroh :}

Perintah Coding jika tombol Darbuka di klick pada menu diatas seperti berikut :

public void onClick(View $v)$ \{ 


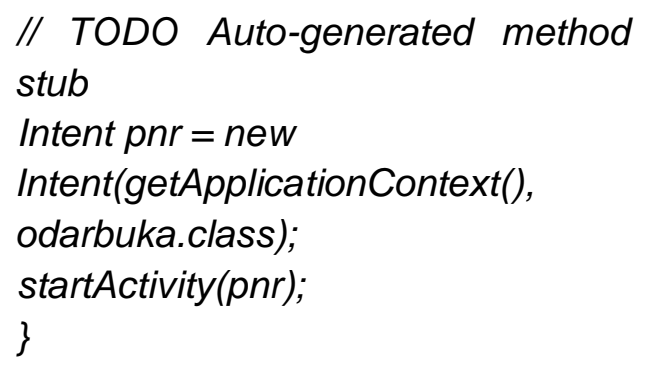

Sedangkan bila tombol Darbuka di klick makan akan ditampilkan halaman yang akan di tampilkan alat music darbuka. Pada gambar darbuka di tengah-tenganya ada tulisan menu, yang bila di tekan/ di klick tulisan tersebut akan mengeluarkan bunyi seperti bunyi alat music darbuka ketika di mainkan.

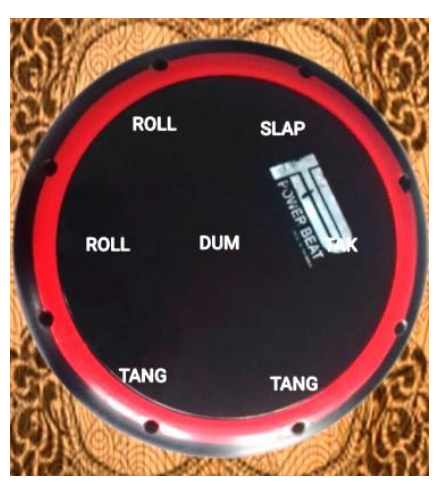

Gambar 3. Alat Musik Darbuka

Perintah Coding pada menu darbuka ini adalah :

public class odarbuka extends

Activity implements OnClickListener \{

Button rol, roll, tangsatu, tangdua, slap, takk, dumm;

MediaPlayer rol1, roll1, tangsatu1, tangdua1, slap1, takk1, dum1;

public void onCreate(Bundle savedInstanceState) \{

super.onCreate(savedInstanceStat e);
this.requestWindowFeature(Windo w.FEATURE_NO_TITLE);

setContentView(R.layout.odarbuka)

$$
\text { rol }=(\text { Button })
$$

findViewByld(R.id.roll1); roll $=($ Button $)$

findViewByld(R.id.roll2); tangsatu $=($ Button $)$

findViewByld(R.id.tang 1); tangdua $=($ Button $)$

findViewByld(R.id.tang2); slap $=($ Button $)$

findViewByld(R.id.slap); takk $=($ Button $)$

findViewByld(R.id.tak); dumm $=$ (Button)

findViewByld(R.id.dum);

$$
\text { rol1 = }
$$

MediaPlayer.create(this, Yy.raw.rol); roll1 =

MediaPlayer.create(this, Yy.raw.roll); tangsatu $1=$

MediaPlayer.create(this,

Yy.raw.tang);

tangdua1 $=$

MediaPlayer.create(this,

Yy.raw.tang);

$$
\text { slap } 1=
$$

MediaPlayer.create(this,

Yy.raw.slep);

takk1 =

MediaPlayer.create(this,

Yy.raw.takdarbuka);

dum 1 =

MediaPlayer.create(this,

Yy.raw.tungdarbuka);

rol.setOnClickListener(this);

roll.setOnClickListener(this);

tangsatu.setOnClickListener(this); 
tangdua.setOnClickListener(this);

$$
\begin{aligned}
& \text { slap.setOnClickListener(this); } \\
& \text { takk.setOnClickListener(this); } \\
& \text { dumm.setOnClickListener(this); } \\
& \text { \} }
\end{aligned}
$$

public void onClick(View $v)$ \{ // TODO Auto-generated method stub switch (v.getld()) \{ case Yy.id.roll1: rol1.start(); break; case Yy.id.roll2: roll1.start(); break;

case Yy.id.tang1: tangsatu1.start(); break;

case Yy.id.tang2: tangdua1.start(); break;

case Yy.id.slap: slap1.start(); break; case Yy.id.tak: takk1.start(); break; case Yy.id.dum: dum1.start(); break; default: break; \}

\}

Pada alat music darbuka seperti gambar 3, tulisan ( roll, slap, tang, dum) akan mengeluarkan suara yang berbeda sesuai suara hasil merekam dari alabt Darbuka sesungguhnya.

\section{KESIMPULAN}

Media pembelajaran multimedia hadroh berbasis handphone android yang telah dibuat dengan judul Rancang Bangun Media Pembelajaran Alat Musik Hadroh Berbasis Android, setelah dilakukan pengujian sudah dapat mengeluarkan suara/bunyi sesuai dengan alat musik rebana dan untuk penggunaan seperti biasanya dapat mengeluarkan suara yang sesuai dengan kebutuhan dan yang di harapkan oleh pengguna atau user.

\section{DAFTAR PUSTAKA}

Arief Multi Hidayat. 2018. Aplikasi Pengenalan Alat Musik Tradisional Indonesia Berbasis Android. Jurnal Evolusi. 2018. 6.2. 98-105

Corel, 2015, Corel VideoStudio User Guide, Corel Corperation.

Jeni Nadik, Moch Subhan M., Mustagfirin, (2017), Aplikasi Rebana Digital Berbasis Android.

Luther,Arc C. (1994). Authoring Interactive Multimedia. AP Professional. Boston

Roemaldo S., Budi S., Idhawati H., 2016. "Game Pembelajaran Alat Musik Tradisional Rebana Berbasis Android".

Solichin. (2015). Sejarah Rebana Kaliwadas. http://www.solichintoip.com/p/sejarah-rebana-kaliwadasbumiayu.html di akses 14 Juli 2019.

Sulistiyanto, S. (2018). Media Pembelajaran Nahwu Dengan Smartphone. Seminastika Universitas Mulia Balikpapan, 1(001), 171-175 